\title{
Water Quality Assessment of Gowrivakkam Lake
}

\author{
L. Maria Subhasini, B. Saritha, S. Rajesh
}

\begin{abstract}
Water is an important precious natural resources on the earth. It is used in irrigation, industries and domestic usage. In this study of water quality assessment of Gowrivakkam lake was carried out. Total of 8 samples was collected from different parts of the Gowrivakkam lake and analysis for various physicochemical parameter like as $\mathrm{pH}$, Alkalinity, Hardness, Chloride, TDS, Fluoride, Ammonia, Phosphate and Nitrite. The analyzed parameter were compared with BIS standards. Quality of lake water in the study area was calculated. The WQI of this lake was found to be good. Therefore, the water can be used only after treatment.
\end{abstract}

Keywords - Water quality Index, pH, Alkalinity, Hardness.

\section{INTRODUCTION}

A lake is a surface source of water, which is stagnant in nature[1]-[5]. Lakes are different from rivers or streams, which are flowing sources of water. Lakes receive water from rivers and streams. Lakes are categorized based on the quality of water present in it as freshwater, brackish or saline lakes.

Fresh water sources throughout the world have become contaminated, and have reduced the portability of the water. Due to the fact that the start of civilization, surface water our bodies were the centre of cultural improvement and anthropogenic interest. The reasons of pollution in these water bodies are without delay associated with human activities. because of the speedy boom in industries and population the exploitation of air, water and soil from the character are also growing[6]-[10]. The pollution like Sulfur dioxide, nitrogen, nitrite, sulfide, carbon dioxide and many others. are the principle causes of air pollutants. The presence of high organic content material, poisonous compounds (manganese, zinc, and mercury), mutagenic detergent and so on. are the pollutants of water pollution. most of the commercial and domestic wastes are disposed off in water with out right treatment which may include diverse pollutants causing additives (B.Saritha and Veda madavan, 2011). Because of this many lakes specifically city lakes are disappearing so speedy on the way to carry far accomplishing results inside the environment which includes adjustments within the micro climate of the regions[11]-[15].

Revised Manuscript Received on October 22, 2019.

Maria Subhasini . L, Department of Civil Engineering, Bharath Institute of Higher Education and Research, Chennai, India. Email: mariasubashini80@gmail.com

B. Saritha, Department of Civil Engineering, Bharath Institute of Higher Education and Research, Chennai , India. Email: sarichaks@ gmail.com

S. Rajesh, Department of Civil Engineering, Bharath Institute of Higher Education and Research, Chennai , India. Email: rajeshskr06@gmail.com

\section{METHODOLOGY}

- Literature review collection.

- Selection of study area.

- Collection of samples from the lake.

- Testing of lake water samples.

- Comparision of the results with the BIS (IS 10500:2012).

- Assessment of Water quality.

- Result and conclusion

\section{A. Study Area}

Gowrivakkam : is a located in Chennai city in Tamil Nadu state, India.

Latitude: $12.9203^{\circ} \mathrm{N}$

Longtitude: $80.1654^{\circ} \mathrm{E}$

Kamarajar salai, medavakkam, Tambaram, Raj Bhawan, Pallikaranai are the nearby localities to Gowrivakkam. Nandivaram- Guduvancherri, Ambattur, Chennai, Thirunindravur are the nearby cities to Chennai. It is near the Bay of Bengal. There is a chance of humidity in the weather.

\section{B. Determination Water Quality Index}

The introduction of Water Quality Index (WQI) is an important tool for determining the extent of pollution[16]-[20]. Water Quality Index is defined as, "a rating reflecting the composite influence of different water quality parameters on overall quality of water"( Priyanka Chugh et al, 2014).

\section{Determination of WQI}

WQI is determined using the formula, $\mathrm{WQI}=\sum \mathrm{qnWn} / \sum \mathrm{Wn}$

\section{RESULTS AND DISCUSSIONS}

Table - 1 Results of WQI

\begin{tabular}{|c|c|c|}
\hline Sample No. & $\begin{array}{l}\text { Water Quality } \\
\text { Index }\end{array}$ & Status \\
\hline 1 & 85.2044 & Good \\
\hline 2 & 104.7256 & Poor \\
\hline 3 & 94.9942 & Good \\
\hline 4 & 83.66408 & Good \\
\hline 5 & 94.86164 & Good \\
\hline 6 & 82.93159 & Good \\
\hline 7 & 74.6278 & Good \\
\hline 8 & 106.1838 & Poor \\
\hline
\end{tabular}




\section{CONCLUSION}

The results of water investigation conducted in our project show that lake contains water of good quality. The water has to be treated before using for drinking and other domestic purposes[21]-[26]. Because of pollution plants are grow rapidly and buried into the lake after decomposition. This continously reduces the quality of the lake water. So concerned Goverment should take strict action to solve the lake contamination (Lodh, R et al, 2014).

The WQI provides a systematic and reliable method to determine the water quality. Discharge of Industrial effluent or sewage water should not be discharged into the water body (Esha Tambe1, Dr.Sulekha Gotmare, 2017). The above results conclude that systematic treatment is required to sustain the water quality for further protection of the lake[30]-[36].

\section{REFERENCES}

1. Sathish Kumar, K., Vinothkumar, S., Venkatakrishnaiah, R. \& Mohan, S.J. 2019, "Experimental investigation on rehabilitation of corroded concrete beam specimens", International Journal of Civil Engineering and Technology, vol. 10, no. 1, pp. 2949-2955.

2. Kanchanabhan, T.E., Krishnaiah, R.V., Dayakar, P. and Mani, A., 2019. A detailed study on green building concept in construction industry. International Journal of Civil Engineering and Technology, 10(1), pp. 2944-2948.

3. Mugilvani, P., Murugan, S.T., Kaviya, B. and Sathishkumar, K., 2019. Experimental investigation on nano concrete. International Journal of Civil Engineering and Technology, 10(1), pp. 907-912.

4. Vinothkumar, S., Sathishkumar, K., Anish, C. and Rajesh, S., 2019. Characteristic strength of concrete by partial replacement with sawdust and waste ceramic tiles. International Journal of Civil Engineering and Technology, 10(1), pp. 2821-2829.

5. Chitra, R., Thendral, S., Arunya, A. and Mohan, S.J., 2019. Experimental study on strength of concrete by partial replacement of fine aggregate with saw dust. International Journal of Civil Engineering and Technology, 10(1), pp. 2766-2769.

6. Mani, A., Meikandaan, T.P., Gowrishankar, P.G. and Kanchanabhan, T.E., 2019. A study on treatment of industrial effluent (dyeing) using moringa oleifera, tamarina indica as coagulants. International Journal of Civil Engineering and Technology, 10(1), pp. 2796-2811.

7. Frank Stephen, S., Chockalingam, M.P., Nalanth, N. and Lekshmy Raghavan, P., 2019. Study on the fresh state properties of self compacting concrete modified with recycled concrete aggregate. International Journal of Civil Engineering and Technology, 10(1), pp. 1205-1212.

8. Dayakar, P., Raman, K.V., Arunya, A. and Venkatakrishnaiah, R., 2019. Study on strength properties of sand by biocementation with eggshell. International Journal of Civil Engineering and Technology, 10(1), pp. 2770-2785.

9. Shendge, R.B., Chockalingam, M.P., Saritha, B. and Ambica, A., 2018. Swat modelling for sediment yield: A case study of Ujjani reservoir in Maharashtra, India. International Journal of Civil Engineering and Technology, 9(1), pp. 245-252.

10. Meikandaan, T.P. and Hemapriya, M., 2017. Use of glass FRP sheets as external flexural reinforcement in RCC Beam. International Journal of Civil Engineering and Technology, 8(8), pp. 1485-1501.

11. Harini, A.T., 2017. Experimental study on utilisation of ceramic wastes in concrete. International Journal of Civil Engineering and Technology, 8(8), pp. 1346-1352.

12. Ambica, A., Sartiha, B. and Anbarasan, R., 2017. Groundwater quality assessment using water quality index and GIS,
Maduravoyal, Chennai, India. International Journal of Civil Engineering and Technology, 8(8), pp. 1375-1381.

13. Aswathy, M., Saritha, B. and Chockalingam, M.P., 2019. Degradation of anionic dye using Fe/Tio2 composite by photocatalysis. International Journal of Innovative Technology and Exploring Engineering, 8(9 Special Issue 3), pp. 788-791

14. Srinivasan, G.R. \& Palani, S. 2018, "Physicochemical analysis and economic evaluation of lake ecosystem - A case study of lake system in Walajah Taluk, Vellore (India)", Water and Energy International, vol. 61RNI, no. 3, pp. 52-55.

15. Srinivasan GR, Palani S, Manohanam A, Jambulingam R. Assessment of Groundwater Quality of Water Samples Collected From Vellore Co-Operative Sugar Mill, Vellore. Asian Man (The)-An International Journal. 2018;12(2):216-8.

\section{AUTHORS PROFILE}

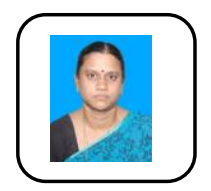

Maria Subhasini L Assistant Professor, Department of Civil Engineering, Bharath Institute of Higher Education and Research, Chennai , India.

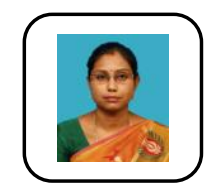

B. Saritha Assistant professor, Department of Civil Engineering, Bharath Institute of Higher Education and Research, Chennai , India.

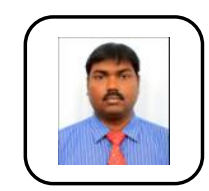

S. Rajesh Assistant Professor, Department of Civil Engineering, Bharath Institute of Higher Education and Research, Chennai, India. 